УДК 621.941

DOI: https://doi.org/10.26642/ten-2020-1(85)-81-88

\author{
О.В. Шевченко, д.т.н., проф. \\ О.В. Ліщінер-Іващенко, аспірант \\ Національний технічний університет Украӥни \\ «КПІ імені Ігоря Сікорського»
}

\title{
Забезпечення вібростійкості процесу розточування однолезовим інструментом на токарному верстаті
}

\begin{abstract}
Підвищення вібростійкості прочесу розточування під час токарної обробки є актуальною задачею. Для теоретичного аналізу коливальних процесів при обробці консольними оправками розроблено принципову схему домінуючої коливальної системи процесу розточування та побудовано математичну модель динамічної системи верстата, щзо дозволяє визначити вплив конструктивних параметрів розточувальних оправок на вібростійкість процесу розточування. На основі математичної моделі з використанням передаточної функиії розімкнутої динамічної системи розраховано залежність запасу сталості пружної системи розточувальна оправкасупорт від конструктивних параметрів оправки. Визначено вплив напряму головних осей жорсткості пружної системи оправка-супорт на статичну характеристику пружної системи інструмента. Експериментальні дослідження розточувальних оправок дали можливість визначити їх частотні характеристики методом гармонічного збурення та використати їх під час моделювання процесу розточування. Показано, щзо забезпечення умов вібростійкої обробки на верстатах консольними оправками може здійснюватися шляхом раціонального вибору їх конструктивних параметрів з урахуванням відповідної орієнтації головних осей жорсткості пружної системи інструмента по відношенню до напряму дії сили різання, вибором раціонального співвідношення жорсткостей оправок за цчими осями та підвищенням демпфірувальної здатності консольної частини оправки.

Ключові слова: токарна обробка; прочес розточування; консольна оправка; орієнтована жорсткість; запас сталості; демпфірування.
\end{abstract}

Актуальність теми. Для процесу токарної обробки литих та штампованих заготовок характерні значні коливання припуску та твердості оброблюваного матеріалу, похибки взаємного розміщення поверхонь, що $є$ причинами низької точності та якості обробки. Найбільш ефективним способом виправлення похибок отворів у таких заготовках $\epsilon$ розточування однолезовим різцем, встановленим у розточувальній оправці. Під час розточування вибір інструмента залежить від діаметра обробки, а довжина чи глибина отвору визначає виліт консолі. При цьому виліт консолі вибирається мінімальним, а діаметр - за можливістю максимальним, що обмежується діаметром отвору оброблюваної деталі. Крім того необхідно забезпечити безперешкодне відведення стружки та достатній радіальний хід інструмента. Вказані обмеження обумовлюють необхідність детального відпрацювання конструкції розточувальної оправки для забезпечення стабільності процесу різання.

Аналіз останніх досліджень. У процесі обробки тангенціальна і радіальна складові сили різання намагаються відтиснути інструмент від заготовки. Тангенціальна складова буде зміщувати інструмент нижче лінії центрів верстата, зменшуючи величину заднього кута. Це зміщення буде найбільше впливати на зниження вібростійкості під час обробки отворів малого діаметра, коли різальна пластина має значний задній кут, щоб уникнути «затирання» обробленого отвору. Відтискання інструмента під дією радіальної складової сили різання призводить до зменшення глибини різання і стоншення стружки, що може призвести до появи додаткових вібрацій. Якщо довжина консольної частини оправки є більшою за їі чотири діаметри, рекомендовано використовувати оправки з демпфером $[1,2]$.

Під час токарної обробки нежорстким консольним інструментом боротьба 3 шкідливими коливаннями є особливо актуальною. До виникнення шкідливих вібрацій найбільш схильна консольна оправка як найменш жорстка ланка технологічної системи верстата. Оправка у процесі розточування здійснює поздовжні, поперечні та крутильні коливання, що найбільш впливають на рівень відносних коливань між інструментом і деталлю. Зниження рівня інтенсивності коливань розточувальних оправок $€$ одним із важливих шляхів підвищення продуктивності, точності та якості оброблених поверхонь [3-5].

Коливання, які виникають під час різання достатньо жорстким інструментом, визначаються властивостями всієї багатоконтурної пружної системи верстата. У випадку обробки нежорсткими розточувальними оправками рівень коливань інструмента визначається жорсткістю та коливаннями самої оправки, а втрата вібростійкості виникає, в основному, на формі їі коливань [5, 6].

Основними причинами виникнення автоколивань під час різання є: нелінійність характеристик сил різання і тертя; інерційність самого процесу різання; зміна площі зрізу та сили різання внаслідок 
координатного зв’язку між процесом різання та рухом за різними координатами пружної системи верстата; обробка за слідом попереднього проходу; періодичні зміни переднього та заднього кутів інструмента при виникненні коливань [7, 8].

Метою розробки $є$ пошук шляхів підвищення вібростійкості процесу розточування на токарних верстатах традиційної компоновки шляхом теоретичного дослідження статичних та динамічних характеристик розточувальних оправок i визначення на основі отриманих результатів напрямів підвищення режимів вібростійкого розточування.

Викладення основного матеріалу. Загалом, процес токарної обробки являє собою тривимірну задачу. Кожна із парціальних пружних систем верстата, система інструмента та система деталі, має просторову орієнтацію головних осей жорсткості із відповідними пружними властивостями в головних напрямах. Зв'язок між парціальними системами здійснюється через силу різання, яка також має просторову спрямованість. Орієнтація головних осей жорсткості не збігається ні з одним із напрямів, на які традиційно розкладається сила різання під час точіння, а саме: осьову $P_{x}$, радіальну $P_{y}$ та тангенціальну $P_{z}$ складові.

Але для більшості реальних динамічних систем токарних верстатів домінуючими є поперечні коливання в площині $y O z$, що визначена в цих дослідженнях системою координат інструмента. Це пов'язано $з$ тим, що жорсткість пружної системи інструмента в напрямі складової $P_{x}$ сили різання значно вища за жорсткості вздовж осей $O y$ та $O z$. Крім того, складова сили різання $P_{x}$ у більшості випадків менша за інші складові. У зв'язку із цим, при моделюванні автоколивальних рухів системи інструмента можна обмежитися розглядом плоскої задачі у двовимірному приближенні.

Відомо, що основним фактором, що впливає на періодичну зміну сили різання, є зміна площі зрізу при відносних переміщеннях інструмента та деталі. Найбільші зміни площі зрізу виникають під час переміщення інструмента в напрямку, нормальному до поверхні різання [8]. Крім того, при автоколиваннях рух парціальних систем протікає траєкторіями, що за формою являють собою викривлений еліпс, який змінюється у часі. Такі відносні рухи систем інструмента і деталі викликають значні зміни площі зрізу. Враховуючи це, зміну площі зрізу можна взяти за основу для аналізу впливу динамічних характеристик пружної системи інструмента на точність обробки.

Як правило, під час обробки різанням одну із парціальних систем замкненої пружної системи верстата (систему інструмента або систему деталі), що здійснює більш інтенсивні за амплітудою коливання, можна вважати домінуючою системою. Наприклад, під час токарної обробки нежорсткої деталі домінуючою, як правило, є система деталі, а під час розточування довгою оправкою - система інструмента. У цих випадках для аналізу можна використовувати домінуючу коливальну систему, замінивши зв'язок парціальних систем через процес різання в замкненій пружній системі дією сили різання.

Для теоретичного аналізу коливальних процесів під час обробки консольними оправками розроблено принципову схему домінуючої коливальної системи процесу розточування (рис. 1).

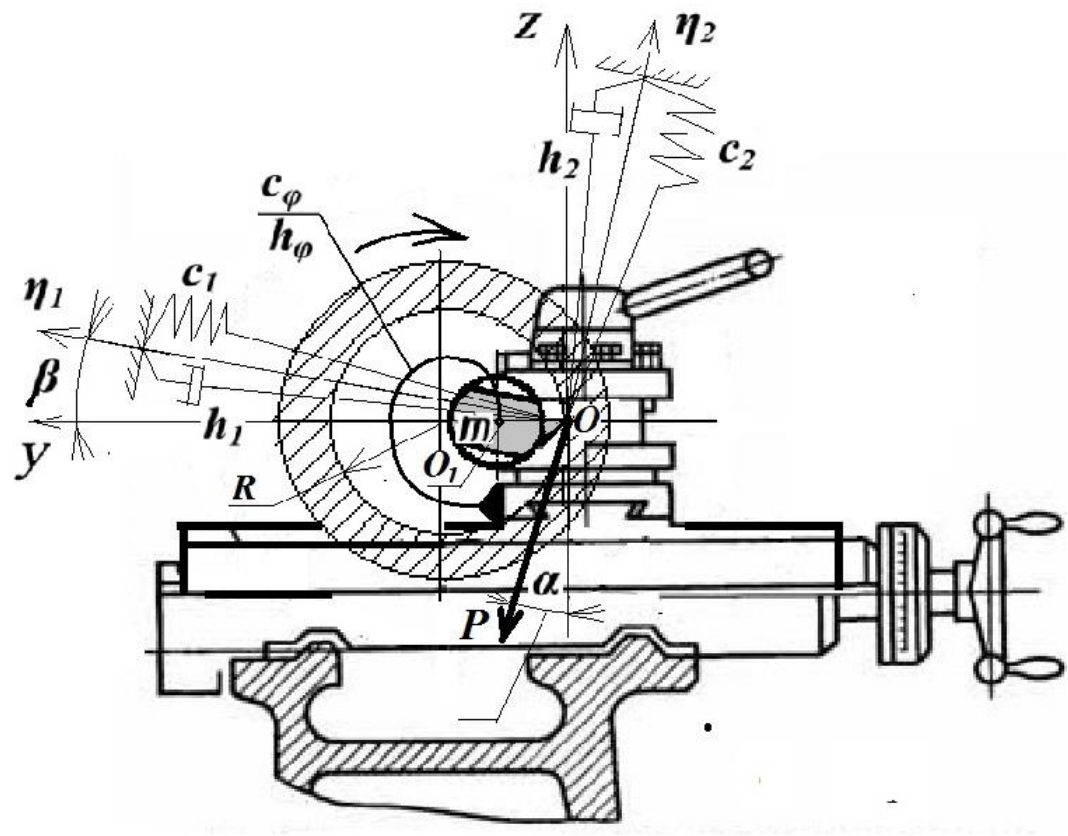

Рис. 1. Принциипова схема процесу розточування 
Під час побудови математичної моделі взяті такі допущення: домінуюча коливальна система розглядається консольна оправка 3 різцем, встановлена в різцетримачі верстата і здійснює обробку деталі; модель побудована з використанням головних координат, що дозволяє повністю розділити змінні, які визначають рух інструмента в довільній в площині $y O z$; маса коливальної системи $m$ приведена до вершини різця; припускається, що маса $m$ рухається тільки в напрямах головних осей координат $O \eta_{1}$ і $O \eta_{2}$; досліджуються тільки коливання в площині $y O z$. На масу $m$ діє сила різання $P(t)$, прикладена до вершини різця. Модель пружної системи інструмента зазначена як система з трьома степенями вільності. За початок координат взято вершину різця (т. $O$ ). Вісь $O y$ спрямовано по нормалі до оброблюваної поверхні, а вісь $O z$ - перпендикулярно до неї. Сила різання $P(t)$ прикладена під кутом $\alpha$ до осі $O z$, а головні координати $O \eta_{1}$ і $O \eta_{2}$ розвернуті під кутом $\beta$ до узагальнених координат $O y$ і $O z$.

3 урахуванням лінійності характеристик жорсткості та пропорційності сили опору швидкості, рівняння руху системи за головними координатами наведено у вигляді:

$$
\left\{\begin{array}{l}
m \cdot \ddot{\eta}_{1}+h_{1} \cdot \dot{\eta}_{1}+c_{1} \cdot \eta_{1}=P(t) \cdot \sin (\beta-\alpha) \\
m \cdot \ddot{\eta}_{2}+h_{2} \cdot \dot{\eta}_{2}+c_{2} \cdot \eta_{2}=-P(t) \cdot \cos (\beta-\alpha) \\
J \cdot \ddot{\varphi}+h_{\varphi} \cdot \dot{\varphi}+c_{\varphi} \cdot \varphi=P(t) \cdot \cos \alpha \cdot R
\end{array},\right.
$$

де $m, J$ - маса та момент інерції системи;

$h_{1}$ і $h_{2}-$ коефіцієнти демпфірування;

$c_{1}$ i $c_{2}$ - коефіцієнти жорсткості в напрямах головних осей координат $O \eta_{1}$ i $O \eta_{2}$, коефіцієнти крутильної жорсткості $c_{\varphi}$ та демпфірування $h_{\varphi}$ навколо осі поздовжньої подачі;

$R$ - поточний радіус обробки.

Для зв'язку узагальнених координат $y$ і $z$ з головними координатами $\eta_{1}$ і $\eta_{2}$ використовують рівняння:

$$
\left\{\begin{array}{l}
y(t)=\eta_{1} \cdot \cos (\beta+\varphi)-\eta_{2} \cdot \sin (\beta+\varphi) \\
z(t)=\eta_{1} \cdot \sin (\beta+\varphi)+\eta_{2} \cdot \cos (\beta+\varphi)
\end{array},\right.
$$

де $\varphi$ - кут повороту оправки навколо осі $x$ від навантаження моментом сили різання $P(t)$ в т. $O$.

Сила різання $P(t)$ зазначається у вигляді [9]:

$$
P(t)=K_{\text {пит }} \cdot a(t) \cdot b(t),
$$

де $a(t)$ і $b(t)$ - поточні значення товщини і глибини зрізу, що змінюються в часі залежно від інтенсивності відносних коливань інструмента і деталі при різанні;

$K_{\text {num }}$ - питома сила різання, що дорівнює $K_{\text {num }}=\sigma_{0} \cdot \xi$,

де $\sigma_{\mathrm{o}}-$ умовне напруження,

$\xi$ - усадка стружки.

Поточне значення приведеної товщини зрізу $a(t)$ можна визначити, якщо величину швидкості $S(t)$ переміщення оправки $(m)$ в напряму поздовжньої подачі поділити на частоту обертання деталі $\omega(t)$. Для моделювання змінних у часі величин $S(t)$ та $\omega(t)$ розроблені математичні моделі приводів подачі інструмента та обертання деталі, що наведені в [10]. Зв'язок рухів цих двох динамічних систем дає можливість отримати значення перемінної у часі товщини зрізу $a(t)$ :

$$
a(t)=\frac{S(t)}{\omega(t)} \cdot 2 \pi
$$

Поточне значення глибини різання визначається складовими:

$$
b(t)=b_{0}+y(t)+e \cdot \sin \omega(t),
$$

де $b_{0}$ - задана глибина різання;

$e$ - ексцентриситет заготовки;

$y(t)$ - пружні деформації інструмента (2).

За базовими виразами (1-5) побудована математична модель динамічної системи процесу розточування, що дозволяє визначити вплив конструктивних параметрів консольних оправок на вібростійкість процесу розточування. На основі системи рівнянь (1) з використанням передаточної функції розімкнутої динамічної системи може бути розраховано залежність запасу сталості пружної системи розточувальна оправка-супорт за критерієм Найквіста в першу чергу від конструктивних параметрів оправки, таких, як їі геометричні розміри, співвідношення жорсткостей за напрямками головних осей координат, коефіцієнтів демпфірування та кута $\beta$. Критерій Найквіста дозволяє не тільки встановити сам факт сталості пружної системи, але і оцінити запас сталості, що в цьому дослідженні $\epsilon$ більш важливим. Запас сталості показує, наскільки далеко знаходиться пружна система від межі втрати сталості.

На рисунку 2 наведено приклад результатів розрахунку запасу сталості пружної системи розточувальна оправка-супорт за амплітудою від вильоту консольної частини оправки діаметром 30 мм та параметрів режиму різання [11]. 


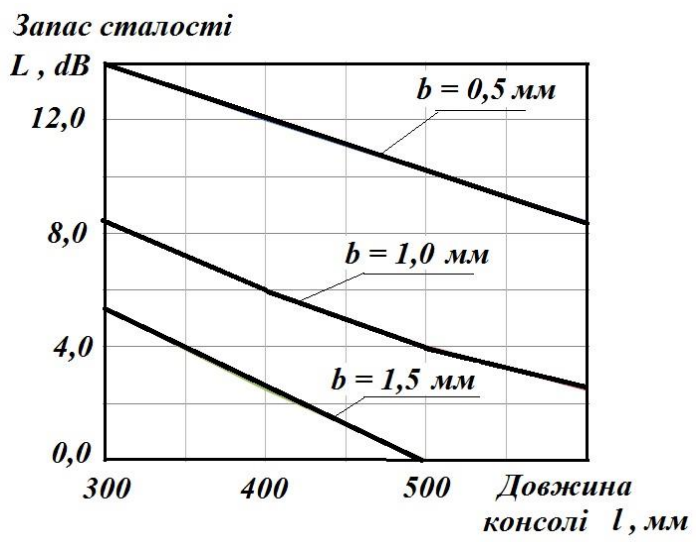

Рис. 2. Залежність запасу сталості по амплітуді L пружної системи інструмента від довжини консольної частини оправки $l$ та глибини різання $b$

Наведені розрахункові значення запасу сталості по амплітуді (рис. 2) отримані при таких початкових параметрах: питома сила різання $K_{\text {num }}=2,3 \cdot 10^{9} \mathrm{H} / \mathrm{M}^{2}$; швидкість різання $V=100 \mathrm{м} /$ хв.; товщина зрізу $a=0,1$ мм; співвідношення коефіцієнтів приведеної жорсткості оправки $c_{2} / c_{1}=0,7$; кути $\alpha=30^{0}$ i $\beta=15^{0}$. За результатами досліджень встановлено, що найбільш сталими під час різання є пружні системи інструмента, у яких виконується умова $\beta=\alpha / 2$ при співвідношеннях приведених жорсткостей у напрямах головних осей координат $\mathrm{c}_{\min } / \mathrm{c}_{\max } \approx 0,7[10]$.

Запас сталості за амплітудою $L(d B)$ визначається за виразом [12]:

$$
L=20 \lg \frac{1}{H}(d B),
$$

де $H$ - відрізок дійсної осі, що є відстанню між початком координат та найближчою до точки $(-1 ;$ і 0$)$ точки перетину годографа Найквіста $з$ дійсною віссю.

Для систем металорізальних верстатів необхідно, щоб $L \geq 8 \div 12(\mathrm{~dB})$.

Вплив напряму головних осей жорсткості на статичну характеристику пружної системи інструмента. Типовий розточувальний інструмент важких токарно-гвинторізних верстатів традиційної компоновки не має явно виражених осей найбільшої і найменшої жорсткості в площині, що перпендикулярна до осі оправки. Це може призвести до суттєвого впливу координатного зв'язку на збільшення амплітуд автоколивань оправки під час різання.

Пружне переміщення системи розточувальна оправка-супорт в напрямку нормалі до оброблюваної поверхні (рис. 1) можна зобразити у вигляді:

$$
y=y_{2}+y_{1}=P \cdot \cos (\beta-\alpha) \cdot \sin \beta / c_{2}-P \cdot \sin (\beta-\alpha) \cdot \cos \beta / c_{1},
$$

де величина $y$ визначає зміну товщини зрізуваного шару.

Відповідно до (7) статичну характеристику пружної системи розточувальна оправка-супорт можна показати у вигляді [9]:

$$
K_{\Pi C}=K_{\Pi C 2}+K_{\Pi C 1},
$$

де $K_{\Pi C_{2}}=y_{2} / P$, а $K_{\Pi C_{1}}=y_{1} / P$.

У випадку від'ємного значення коефіцієнта $K_{П С}$ відбувається занурення різця у заготовку, тобто переміщення різця направлене назустріч складовій $P_{y}$ сили різання (ефект «від’ємної» жорсткості).

В результаті із врахуванням (7) та (8) отримаємо статичну характеристику системи розточувальна оправка-супорт у вигляді:

$$
K_{\Pi C}=y / P=\cos (\beta-\alpha) \cdot \sin \beta / c_{2}-\sin (\beta-\alpha) \cdot \cos \beta / c_{1} .
$$

Якщо встановити діапазон значень коефіцієнтів жорсткості $c_{1}$ та $c_{2}$ пружної системи розточувальна оправка-супорт в напрямку головних осей координат $O \eta_{1}$ і $O \eta_{2}$, то за допомогою виразу (9) є можливість визначити зону знаходження кута розвороту $\beta$ головних осей жорсткості пружної системи, в якій ця система буде мати найменшу податливість i, відповідно, буде забезпечена найбільша точність обробки.

Аналіз результатів розрахунків статичної характеристики пружної підсистеми інструмента [13]

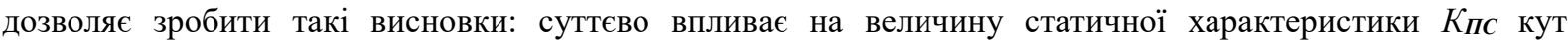
розвороту $\beta$ головних осей жорсткості та рівень співвідношення жорсткостей елементів підсистеми; графічно та аналітично можна визначити параметри пружної підсистеми, за яких існує «від'ємна» жорсткість $\left(K_{\Pi \boldsymbol{C}}<0\right)$; рекомендується кут розвороту $\beta$ головних осей жорсткості наближати за величиною до половини кута $\alpha$, який визначає напрямок дії сили різання $P$. 
Для визначення необхідності врахування кута розвороту $\beta$ головних осей жорсткості при моделюванні процесу розточування на важкому токарно-гвинторізному верстаті мод. 1 М63 проведені експериментальні дослідження, результати яких наведено на рисунку 3.

На рисунку 3 наведено схему вимірювання кругової податливості супортної групи верстата. Особливістю схеми вимірювання $є$ те, що навантаження здійснюється на вильоті консолі $L=250$ мм, закріпленої в різцетримачі розточувальної оправки діаметром консольної частини 85 мм. Силова дія на оправку здійснюється навантажувальним пристроєм у вигляді Г-подібного кронштейна 3 гвинтовим домкратом, що встановлений у затискному патроні шпинделя верстата. Між кронштейном та оправкою встановлено динамометр камертонного типу. Напрямок дії сили змінюється поворотом кронштейна разом зі шпинделем через $30^{\circ}$, забезпечуючи 12 напрямів навантаження супортної групи (поз. 1-12). Переміщення оправки на вильоті консолі внаслідок дії навантаження фіксується індикаторами часового типу $I_{2}$ та $I_{6}$ ціною поділки 0,002 мм, які контролюють переміщення оправки в горизонтальному та вертикальному напрямках відповідно. Положення індикаторів є незмінним під час зміни напрямі дії навантажувальної сили. Переміщення консольної частини оправки вимірювалося при двох рівнях навантаження $\mathrm{P}=2500 \mathrm{H}$ та $\mathrm{P}=3500 \mathrm{H}$.

Аналіз графіків кругової діаграми податливості при різних рівнях навантаження (рис. 3,6$)$ дозволив визначити положення головних осей жорсткості супортної групи, а саме, $\eta_{1}$ - вісь найменшої жорсткості та $\eta_{2}$ - вісь найбільшої жорсткості і кут їх розвороту $\beta \approx 30^{0}$ відносно довільної системи координат уOz.

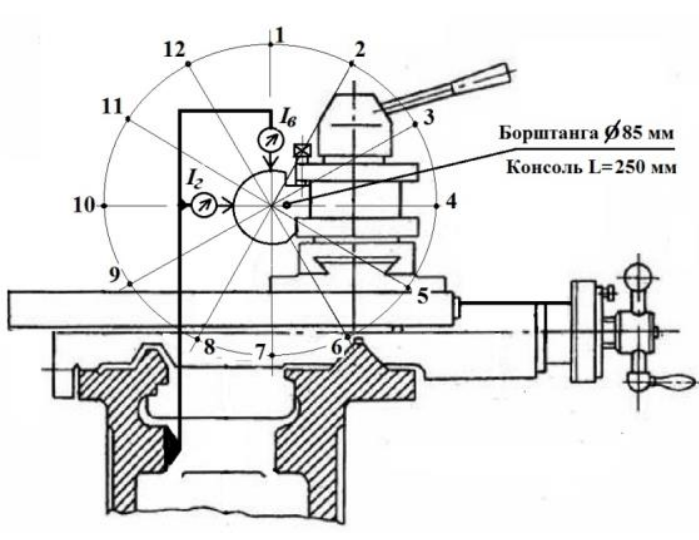

a)

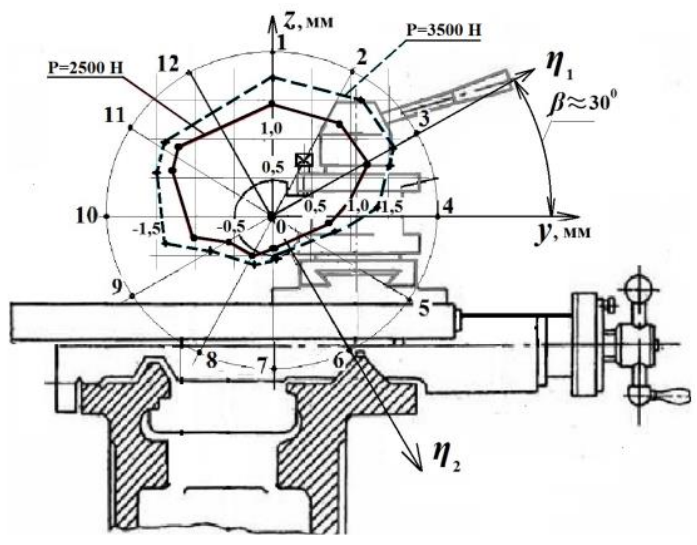

б)

Рис. 3. Схема вимірювання (а) кругової податливості та графіки деформацій (б) у площині, перпендикулярної до вісі шпинделя, пружної системи розточувальна оправка-супорт токарногвинторізного верстата мод. 1 М63

Визначене положення головних осей жорсткості супортної групи забезпечує сталий процес різання під час зовнішнього точіння внаслідок того, що сила різання є близькою за напрямом до осі найбільшої жорсткості $\eta_{2}$ (напрямок 0-6) і Кпс > 0. Разом з тим, при розточуванні з правим обертанням шпинделя напрямок дії сили різання буде наближеним до напрямку 0-8 і Кпс може бути < 0, що призведе до втрати сталості процесу різання внаслідок «від'ємної» жорсткості та затягування різця в матеріал деталі. Одним зі способів уникнення затягування різця при цій схемі розточування може бути обробка 3 лівим обертанням шпинделя, за якої напрямок дії сили різання відносно головних осей жорсткості буде аналогічним процесу зовнішнього точіння.

Таким чином, для забезпечення умов вібростійкої обробки розточувальними оправками на важких токарних верстатах бажано враховувати під час проектування оправок такі рекомендації: максимально підвищити радіальну жорсткість оправки в зоні встановлення різця за рахунок форми поперечного перерізу консольної частини та в зоні кріплення на верстаті; забезпечити умову, за якої збільшення сили різання викликає відтиск інструмента від оброблюваної деталі.

Підвищення демпфірувальної здатності розточувальної оправки. Одним із ефективних способів підвищення вібростійкості процесу розточування $є$ підвищення демпфірувальної здатності розточувальних оправок. У більшості відомих конструкцій оправок для встановлення демпфера використовується значна частина внутрішнього об'єму тіла консольної частини оправки. Недоліком такого розточувального інструмента є його низька радіальна жорсткість в точці розміщення різця внаслідок наявності порожнини значного діаметра в корпусі для розміщення демпфірувального елемента, що обмежує можливості використання цього розточувального інструмента тільки режимами тонкого розточування з невеликими силами різання [1]. 
Для визначення впливу діаметра порожнини консольної частини оправки на величину прогину $y$ вільного кінця консолі від зосередженого зусилля $P$ використаємо формулу [14]:

$$
y=\frac{P \cdot l^{3}}{3 E \cdot J},
$$

де $l$ - довжина консолі;

$E$ - модуль пружності матеріалу оправки;

$J$ - осьовий момент інерції перерізу консолі.

Більшість розточувальних оправок верстатів токарної групи мають циліндричну форму консолі, відповідно осьовий момент інерції перерізу кола та кільця визначають за формулами:

для кола

$$
J_{y}=\frac{\pi \cdot D^{4}}{64},
$$

а для кільця

$$
J_{y}=\frac{\pi \cdot D^{4}}{64}\left[1-\left(\frac{d}{D}\right)^{4}\right] .
$$

Із порівняння цих формул бачимо, що вплив діаметра $d$ порожнини на збільшення прогину у вільного кінця консолі буде не більше за $5 \%$, якщо співвідношення $d / D \leq 0,475$, або після округлення $d / D \leq 0,5$. При виконанні цієї умови втрачається близько $5 \%$ радіальної жорсткості консольної частини оправки і $\epsilon$ можливість встановлення демпфера в порожнині оправки для підвищення ії демпфірувавльної здатності i, як наслідок, підвищення вібростійкості під час розточування [15].

Для підтвердження вказаного положення розроблено твердотільну модель оправки з внутрішнім отвором для встановлення демпфера. При розрахунках співвідношення між діаметром порожнини $d$ та зовнішнім діаметром $D$ консольної частини оправки змінювалося в діапазоні $0,45<d / D<0,9$, при незмінному $D=34$ мм та $l=250$ мм.

На рисунку 4 наведено графіки залежності радіальної жорсткості консольної частини оправки від співвідношення $d / D$.
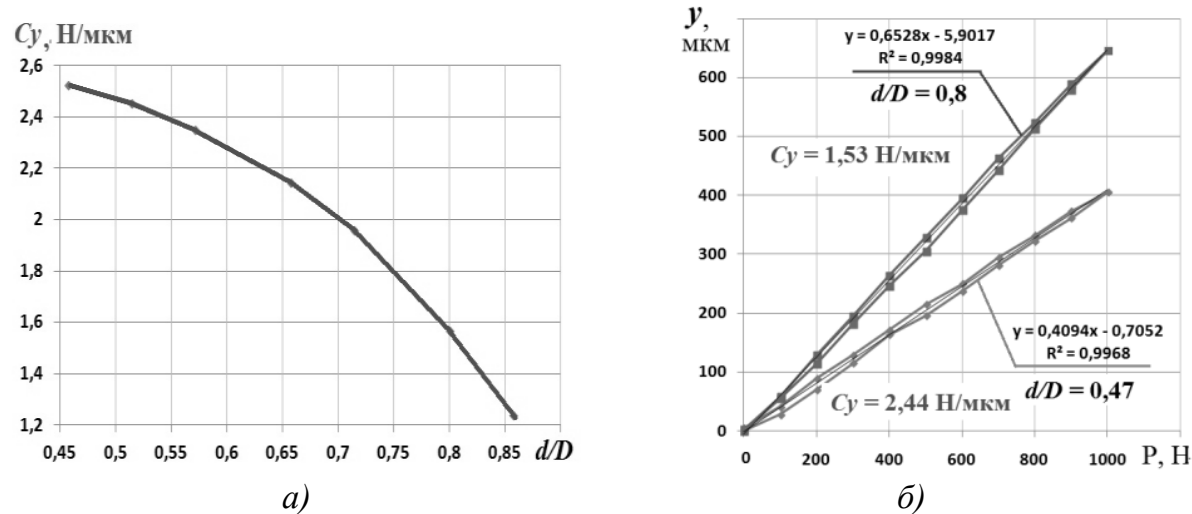

Рис. 4. Графік розрахункової залежності радіальної жорсткості с с консольної частини оправки від співвідношення діаметра отвору д до зовнішнього діаметра консолі $D=34 \mathrm{мм} \mathrm{(a)} \mathrm{при} l=250$ мм та

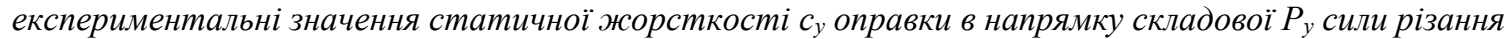
з різними діаметрами отвору $d$ в консолі оправки (б)

Радіальна жорсткість вільного кінця консолі оправки із суцільної сталі, розрахована за формулою (10) та при $D=34$ мм, $l=250$ мм і $d=16$ мм, становить $c_{y}=2,64 \mathrm{H} /$ мкм. Якщо задати умову втрати радіальної жорсткості консолі не більше $5 \%$, то результати розрахунків методом скінченних елементів (рис. $4, a$ ) повністю підтверджують умову $d / D \leq 0,5$.

Для підтвердження результатів розрахунків виконано експериментальні дослідження статичної жорсткості двох зразків оправок зовнішнього діаметра консолі $D=34$ мм, довжиною консолі $l=250$ мм та співвідношеннями внутрішнього та зовнішнього діаметрів $d / D=0,47$ та $d / D=0,8$. За результатами вимірювань, отримані значення радіальної жорсткості консольних частин оправок при різних співвідношеннях внутрішнього та зовнішнього діаметрів: при $d / D=0,47$ жорсткість $c_{y}=2,44 \mathrm{H} /$ мкм; при $d / D=0,8$ жорсткість $c_{y}=1,53 \mathrm{H} /$ мкм (рис. 4, б).

Значення жорсткостей, отриманих за результатами обробки вимірювань деформацій, підтвердили їх відповідність до результатів розрахунків і дозволили остаточно сформулювати таке: для забезпечення в 
точці різання радіальної жорсткості консольної частини розточувальної оправки з порожниною на рівні жорсткості суцільного тіла консольної частини необхідно витримати умову, щоб діаметр порожнини $d$ не перевищував половини зовнішнього діаметра $D$ консольної частини корпусу оправки, a саме: $d / D \leq 0,5[15]$.

Виконання цієї умови забезпечує достатню радіальну жорсткість консольної частини оправки та можливість встановлення демпфера в порожнині оправки для підвищення її демпфірувальної здатності i, як наслідок, підвищення вібростійкості під час розточування на верстатах токарної групи.

Результати порівняння ефективності розсіяння енергії коливань у консольній частині оправки 3 центральним отвором без демпфера і з вбудованим демпфером, виготовлені з дотриманням умови, щоб діаметр порожнини $d$ не перевищував половини діаметра $D$ консольної частини корпусу оправки, зазначені на рисунку 5. Як бачимо із графіків, час від імпульсного впливу (удару) на консольну частину оправки до усталених коливань зменшується майже в 5 разів для оправки 3 демпфером.
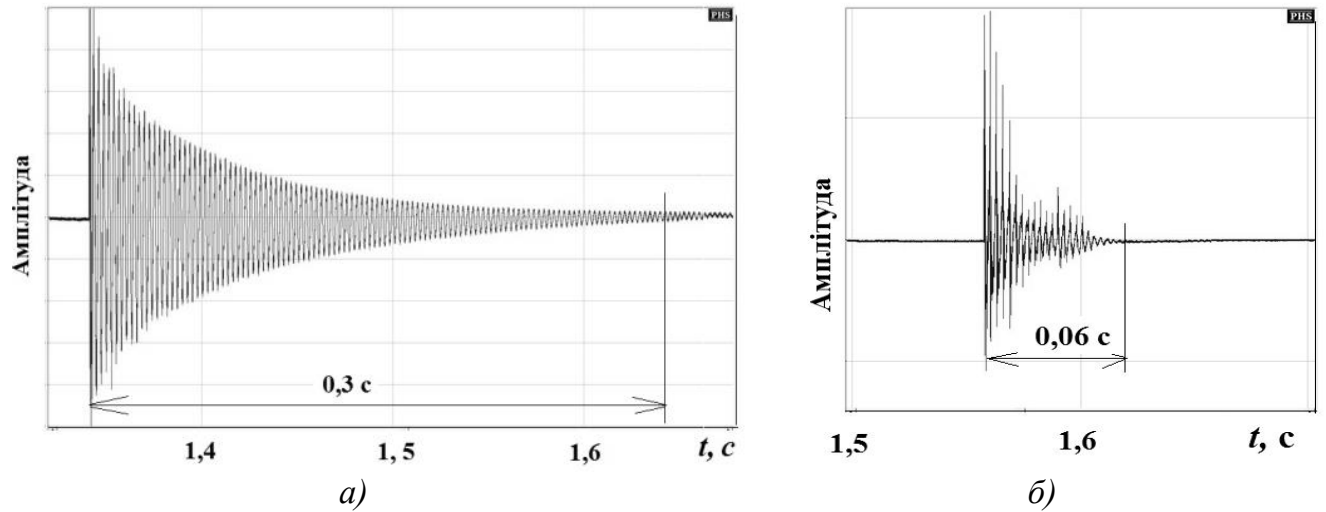

Рис. 5. Графіки затухаючих коливань консольної частини оправки з отвором без демпфера (a) та 3 демпфером (б), щзо мають зовнішній діаметр $D=34$ мм, діаметр отвору $d=16$ мм і довжину консольної частини 250 мм

Висновок. Для забезпечення умов вібростійкої обробки розточувальними оправками на токарних верстатах бажано враховувати при проектуванні оправок такі рекомендації: максимально підвищити радіальну жорсткість оправки в зоні встановлення різця за рахунок форми поперечного перерізу консольної частини та в зоні кріплення на верстаті, при цьому виліт консолі вибирати мінімальним, а діаметр, по можливості, максимальним; забезпечити умову, за якої збільшення сили різання викликає відтиск інструмента від оброблюваної деталі; для підвищення демпфірувальної здатності консольних оправок можна рекомендувати конструкцію з центральним отвором (для демпфера), діаметр якого не має перевищувати половини зовнішнього діаметра оправки.

\section{Список використаної літератури:}

1. Damped Tools from Sandvik Coromant. Silent Tools. / SANDVIK Coromant, 2012. - 100 с. [Електронний pecypc]. - Режим доступу : https://www.sandvik.coromant.com/en-gb/products/silent_tools/pages/default.aspx.

2. Стреляная Ю.О. Динамическая модель процесса растачивания / Ю.О.Стреляная, Д.А. Каинов, А.П. Фалалеев // Машиноприладобудування та транспорт : зб. наук. пр. - Севастополь : Вісник СевНТУ. 2012. - Вип. 129. - С. 229-231.

3. Östling D. Modelling chatter stability in boring operations / D. Östling // Proceeding of ISMA. - 2014. - C. 3647-3654.

4. Rezig A. Suppressing boring bar vibrations by parametric excitation / A.Rezig, M.Ouali // Advances in Production Engineering and Management. - 2012. - № 4. - C. 237-244.

5. Totis G. Robust Analysis of Stability in Internal Turning / G.Totis, M.Sortino // Procedia Engineering. - 2014. № 69. - C. 1306-1315.

6. Senthil Kumar M. A case study on vibration control in a boring bar using particle damping / M.Senthil Kumar, K.M. Mohanasundaram, B.Sathishkumar // International Journal of Engineering Science and Technology. - 2011. T. 3. - № 8. - C. 177-184.

7. Хорошайло В.В. Повышение виброустойчивости растачивания на токарно-винторезных станках / B.В. Хорошайло // Технологический аудит и резервы производства. - 2016. - № 1/1 (27). - С. 17-21.

8. Жарков И.Г. Вибрации при обработке лезвийным инструментом / И.Г. Жарков. - Л. : Машиностроение, 1986. $-184 \mathrm{c}$.

9. Кудинов В.A. Автоколебания на низких и высоких частотах (устойчивость движений) при резании / В.А. Кудинов // Станки и инструмент. - 1997. - № 2. - С. 16-21.

10. Шевченко $O . B$. Методи підвищення сталості процесу різання при токарній обробці нежорским інструментальним оснащенням / О.В. Шевченко // Машинознавство. - Київ, 2009. - № 8 (146). - С. 16-23. 
11. Шевченко O.B. Дослідження вібростійкості консольного інструменту при розточуванні на токарних верстатах / О.В. Шевченко, А.В. Яиник // Технологічні комплекси. - Луцьк : Луцький НТУ, 2014. № 1 (9). - С. 145-149.

12. Петраков Ю.В. Автоматичне управління процесами обробки матеріалів різанням : навч. посіб. / Ю.В. Петраков. - Київ : УкрНДІАТ, 2003. - 383 с.

13. Динамика станочно-инструментальной оснастки для высокоэффективной токарной обработки : монография / Ю.Н. Кузнецов, О.И. Драчев, И.В. Луции и др. - Старый Оскол : ТНТ, 2015. - 432 с.

14. Опір матеріалів : підруч. / Г.С. Писаренко, О.Л. Квітка, Е.С. Уманський ; за ред. Г.С. Писаренка. - 2-ге вид. допов. і перероб. - Київ : Вища школа, 2004. - 655 с.

15. Патент на корисну модель МПК В23В. Розточувальна оправка / О.В. Шевченко, А.В. Яиник, А.Ю. Беляєва. - № 117470 ; заявл. 29.02. опуб. 26.06.2017, Бюл. № 12. - 3 с.

\section{References:}

1. «Damped Tools from Sandvik Coromant. Silent Tools» (2012), SANDVIK Coromant, 100 p., [Online], available at: https://www.sandvik.coromant.com/en-gb/products/silent_tools/pages/default.aspx

2. Streljanaja, Ju.O., Kainov, D.A. and Falaleev, A.P. (2012), «Dinamicheskaja model' processa rastachivanija», Mashynopryladobuduvannja ta transport, zb. nauk. pr., Visnyk SevNTU, Sevastopol', Issue 129, pp. 229-231.

3. Östling, D. (2014), «Modelling chatter stability in boring operations», Proceeding of ISMA2014 Including USD2014, pp. 3647-3654.

4. Rezig, A. and Ouali, M. (2012), «Suppressing boring bar vibrations by parametric excitation», Advances in Production Engineering and Management, No. 4, pp. 237-244.

5. Totis, G. and Sortino, M. (2014), «Robust Analysis of Stability in Internal Turning», Procedia Engineering, No. 69, pp. 1306-1315.

6. Senthil Kumar, M., Mohanasundaram, K.M. and Sathishkumar, B. (2011), «A case study on vibration control in a boring bar using particle damping», International Journal of Engineering Science and Technology, Vol. 3, No. 8, pp. 177-184.

7. Horoshajlo, V.V. (2016), «Povyshenie vibroustojchivosti rastachivanija na tokarno-vintoreznyh stankah», Tehnologicheskij audit i rezervy proizvodstva, No. 1/1 (27), pp. 17-21.

8. Zharkov, I.G. (1986), Vibracii pri obrabotke lezvijnym instrumentom, Mashinostroenie, L., 1986, 184 p.

9. Kudinov, V.A. (1997), «Avtokolebanija na nizkih i vysokih chastotah (ustojchivost' dvizhenij) pri rezanii», Stanki $i$ instrument, No. 2, pp. 16-21.

10. Shevchenko, O.V. (2009), «Metody pidvyshhennja stalosti procesu rizannja pry tokarnij obrobci nezhorskym instrumental'nym osnashhennjam», Mashynoznavstvo, Kyi'v, No. 8 (146), pp. 16-23.

11. Shevchenko, O.V. and Jashnyk, A.V. (2014), «Doslidzhennja vibrostijkosti konsol'nogo instrumentu pry roztochuvanni na tokarnyh verstatah», Tehnologichni kompleksy, Luc'kyj NTU, Luc'k, No. 1(9), pp. 145-149.

12. Petrakov, Ju.V. (2003), Avtomatychne upravlinnja procesamy obrobky materialiv rizannjam, navch. posib., UkrNDIAT, Kyi'v, $383 \mathrm{p}$.

13. Kuznecov, Ju.N., Drachev, O.I., Luciv, I.V., Shevchenko, A.V. and Voloshin, V.N. (2015), Dinamika stanochnoinstrumental'noj osnastki dlja vysokojeffektivnoj tokarnoj obrabotki, monografija, TNT, Staryj Oskol, $432 \mathrm{p}$.

14. Pysarenko, H.S., Kvitka, O.L. and Umans'kyj, E.S. (2004), Opir materialiv, pidruchnyk, in Pysarenko, H.S. (ed.), 2-he vyd. dopov. i pererob, Vyscha shkola, Kyiv, 655 p.

15. Shevchenko, O.V., Yashnyk, A.V. and Beliaieva, A.Yu. (2017), Roztochuval'na opravka, Patent na korysnu model No. 117470: MPK V23V, zajav. 29.02., opub. 26.06.2017, Biul. No. 12, 3 p.

Шевченко Олександр Віталійович - доктор технічних наук, професор Національного технічного університету України «КПІ імені Ігоря Сікорського».

Наукові інтереси:

- дослідження статичних та динамічних характеристик металообробного обладнання;

- дослідження методів підвищення вібростійкості токарної обробки.

http://orcid.org/0000-0003-2015-1239.

E-mail: o.shevchenko@kpi.ua.

Ліщинер-Іващенко Ольга Вадимівна - аспірантка кафедри конструювання верстатів та машин Національного технічного університету України «КПІ імені Ігоря Сікорського».

Наукові інтереси:

- підвищення вібростійкості процесу розточування на токарних верстатах.

http://orcid.org/0000-0002-8630-5758.

E-mail: ole4ka_lime7@i.ua. 